\title{
Thermal properties of polymethylvinylborosiloxanes
}

\author{
Jerzy J. Chruściel • Grażyna Janowska • \\ Marzena Fejdyś
}

Received: 21 February 2011/ Accepted: 4 April 2012/Published online: 19 May 2012

(C) The Author(s) 2012. This article is published with open access at Springerlink.com

\begin{abstract}
New branched polymethylvinylborosiloxanes (PMVBSs) with random structures were prepared, and their chemical structures were studied by spectroscopic methods (FTIR, ${ }^{1} \mathrm{H}-,{ }^{29} \mathrm{Si}-$, and ${ }^{11} \mathrm{~B}-\mathrm{NMR}$ ) and elemental analysis $(\% \mathrm{C}, \% \mathrm{H}, \% \mathrm{Si}$, and $\% \mathrm{~B})$. Average molecular weights $M_{\mathrm{w}}$ and $M_{n}$ were determined by a size exclusion chromatography (SEC), and dynamic viscosities were measured in Brookfield cone-plate reoviscometer HBDV-II+cP. Thermal properties of PMVBSs were studied under air and under nitrogen atmosphere. Thermal curves were interpreted from the point of view of physical and chemical transitions, taking place during the heating process of PMVBSs. Parameters of their thermal stabilities and glass transition temperatures $\left(T_{\mathrm{g}}\right)$ were determined. The synthesized PMVBSs are characterized by low glass transition temperatures $\left(T_{\mathrm{g}}\right.$ : from -122 to $\left.-137^{\circ} \mathrm{C}\right)$ which depend on their chemical structures. It was concluded that gaseous products (such as volatile siloxanes, silanes, $\mathrm{CO}_{2}, \mathrm{H}_{2} \mathrm{O}$, $\mathrm{CH}_{2} \mathrm{O}$, methanol, and formic acid), which could be liberated during the heating process of PMVBSs, promote ceramization processes, leading to the formation of the ceramics of a type $\mathrm{SiBCO}-\mathrm{a}$ borosilicate glass and silica.
\end{abstract}

Keywords Polymethylvinylborosiloxanes ·

Thermal curves - Thermal properties - Thermal stability . Glass transitions

J. J. Chruściel ( $\square)$ · G. Janowska · M. Fejdyś

Faculty of Chemistry, Institute of Polymer and Dye Technology,

Technical University of Łódź, Stefanowskiego 12/16 St.,

90-924 Łódź, Poland

e-mail: jchrusci@p.lodz.pl

\section{Introduction}

The development of a contemporary technique prompts an increase in the demand for polymeric materials with special properties, which are resistant to the influence of low and high temperatures, are slow-burning, and have good mechanical strength. In order to fulfill these requirements and find new materials and technologies of their production, numerous efforts are undertaken. One of such possibilities is the chemical synthesis of new copolymers. In recent years, intensive studies concerning synthesis and applications of hybrid inorganic-organic polymers have been developed. An important group of these polymers are polyborosiloxanes (PBS) [1].

The PBS have thermodynamically stable linkages, but are non-resistant to hydrolysis [2]. Although it is known from the literature information that the presence of trivalent metals causes increase of thermal stability of materials, nevertheless an effect of boron atoms on thermooxidative stability under air atmosphere was studied so far only in a limited range [3]. Thermogravimetric studies proved a high thermal stability of PBS, which is the result of high dissociation energy of $\mathrm{Si}-\mathrm{O}$ and $\mathrm{B}-\mathrm{O}$ bonds, and moreover it is the result of high crosslinking degree of these polymers and the presence of phenyl groups in their macromolecules.

The PBS have found many comprehensive practical applications, for instance, as substances for decreasing the flammability of polyethylene terephtalate (PET) [4]. PBS were added to PET, together with montmorillonite nanoparticles. This system of fire retardants substantially decreased the flammability of PET and contributed to a formation of thick multi-cellular borosiloxane-carbon coatings during polymer combustion. These coatings acted as a barrier for a flame, smoke, and oxygen [4]. Marosi and coworkers [5] had applied PBS as flame retardants for 
polyolefines. The addition of PBS to polypropylene (PP) caused the increase of a viscosity and viscoelasticity during the melting of PP and the decrease of the polymer flammability. PBS cumulated on a PP surface during combustion process and prevented the spreading of a flame, forming a protective coating, and thus deterring any contact with the flame [5]. Other boron compounds (e.g., boric acid and borax) [6, 7]; silanes; silicon-containing polymers: siloxanes, silsesquioxanes [6], and inorganic silicates, e.g., modified montmorillonites [8-10]; and halloysite nanotubes $[11,12]$ were successfully used as halogen-free fire retardants. Ammonium polyphosphate, microencapsulated with a low molecular weight polydimethylsiloxane- $\alpha, \omega$ diol, showed enhanced water resistance and significantly improved flame resistance properties as compared with an unmodified ammonium polyphosphate in a thermoplastic polyurethane composites [13].

In this article, we present the results of our studies concerning thermal properties of the synthesized, new branched polymethylvinylborosiloxanes (PMVBSs) which have not been described in the literature so far. We are going to use these copolymers as modifiers of diene elastomers.

\section{Experimental}

The focus of our studies are the chosen new branched PMVBSs. Their characteristics are given in Table 1. They were synthesized in the following way. In reactions of boric acid $\mathrm{B}(\mathrm{OH})_{3}$ with a large excess of dichlorodimethylsilane $\mathrm{Me}_{2} \mathrm{SiCl}_{2}$, in a dry diethyl ether, a borosiloxane precursor tris(chlorodimethylsilyl)borate $\mathrm{B}\left(\mathrm{OSiMe}_{2} \mathrm{Cl}\right)_{3}$ was prepared. PMVBSs with random, and branched structures were prepared by a hydrolytic copolycondensation of ether solution of the borosiloxane precursor $\mathrm{B}\left(\mathrm{OSiMe}_{2} \mathrm{Cl}\right)_{3}$ and appropriate stoichiometric amounts of chlorosilanes (selected according to predicted chemical structures of PMVBSs): dichlorodimethylsilane $\mathrm{Me}_{2} \mathrm{SiCl}_{2}$, trichloromethylsilane, $\mathrm{MeSiCl}_{3}$, chlorotrimethylsilane, $\mathrm{Me}_{3} \mathrm{SiCl}$, and methylvinyldichlorosilane, $\mathrm{MeViSiCl}_{2}$ with stoichiometric quantity of water, in the presence of pyridine as $\mathrm{HCl}$ acceptor $[14,15]$.

\section{Synthesis of $\mathbf{B}_{9} \mathrm{O}_{14} \mathbf{T}_{6}^{\prime} \mathbf{D}_{124} \mathrm{D}_{31}^{\mathrm{vi}} \mathbf{M}_{17}\left(\mathrm{~B}_{9} \mathrm{~T}_{6}\right)$}

To one-necked round bottom flask with a volume $250 \mathrm{ml}$, equipped with a reflux condenser and a drying tube filled

Table 1 Results of determination of molecular weights (by SEC method), elemental analysis, and the contents of Si-Vi groups [15]

\begin{tabular}{|c|c|c|c|c|c|c|c|c|c|c|c|c|c|c|}
\hline \multirow[t]{2}{*}{$\begin{array}{l}\text { Predicted } \\
\text { composition } \\
\text { of PMVBSs }\end{array}$} & \multirow[t]{2}{*}{$\begin{array}{l}M_{n} \\
\text { calc. }\end{array}$} & \multirow[t]{2}{*}{$M_{n}$} & \multirow[t]{2}{*}{$M_{\mathrm{w}}$} & \multirow[t]{2}{*}{$\begin{array}{l}M_{\mathrm{w}} / \\
M_{n}\end{array}$} & \multicolumn{2}{|l|}{$\% \mathrm{C}$} & \multicolumn{2}{|l|}{$\% \mathrm{H}$} & \multicolumn{2}{|l|}{$\% \mathrm{~B}$} & \multicolumn{2}{|l|}{$\% \mathrm{Si}$} & \multicolumn{2}{|c|}{$\begin{array}{l}\text { The content of } \\
\mathrm{Si}-\mathrm{Vi} \text { groups/ } \\
\mathrm{mol} / 100 \mathrm{~g}\end{array}$} \\
\hline & & & & & Calc. & Found & Calc. & Found & Calc. & Found* & Calc. & Found & Calc. & Found $* *$ \\
\hline $\mathrm{B}_{3} \mathrm{O}_{2} \mathrm{D}_{190} \mathrm{D}_{19}^{\mathrm{vi}} \mathrm{M}^{\prime}{ }_{5}$ & 16,237 & 3,310 & 7,150 & 2.16 & 33.44 & $\begin{array}{l}33.75 \\
33.79\end{array}$ & 8.06 & $\begin{array}{l}8.13 \\
8.32\end{array}$ & 0.20 & 0.17 & 37.02 & 37.21 & 0.117 & 0.107 \\
\hline $\mathrm{B}_{6} \mathrm{O}_{5} \mathrm{D}_{180} \mathrm{D}_{10}^{\mathrm{vi}} \mathrm{M}_{8}^{\prime}$ & 15,809 & 3,020 & 7,430 & 2.46 & 32.97 & $\begin{array}{l}33.15 \\
33.31\end{array}$ & 8.11 & $\begin{array}{l}8.31 \\
8.44\end{array}$ & 0.41 & 0.31 & 37.36 & 37.70 & 0.053 & 0.063 \\
\hline $\mathrm{B}_{9} \mathrm{O}_{8} \mathrm{D}_{190} \mathrm{D}_{10}^{\mathrm{vi}} \mathrm{M}_{11}^{\prime}$ & 16,157 & 3,260 & 7,070 & 2.17 & 32.93 & $\begin{array}{l}33.30 \\
33.37\end{array}$ & 8.10 & $\begin{array}{l}8.29 \\
8.39\end{array}$ & 0.58 & 0.46 & 36.68 & 37.25 & 0.056 & 0.062 \\
\hline $\mathrm{B}_{3} \mathrm{O}_{8} \mathrm{~T}_{6}^{\prime} \mathrm{D}_{76} \mathrm{D}_{19}^{\mathrm{vi}} \mathrm{M}_{11}^{\prime}$ & 8,673 & 1,900 & 4,180 & 2.20 & 34.34 & $\begin{array}{l}34.51 \\
34.74\end{array}$ & 7.98 & $\begin{array}{l}8.14 \\
8.30\end{array}$ & 0.37 & 0.27 & 36.27 & 36.74 & 0.218 & 0.240 \\
\hline $\mathrm{B}_{3} \mathrm{O}_{11} \mathrm{~T}_{9}^{\prime} \mathrm{D}_{100} \mathrm{D}_{25}^{\mathrm{vi}} \mathrm{M}^{\prime}{ }_{14}$ & 11,415 & 2,370 & 4,690 & 1.98 & 34.30 & $\begin{array}{l}34.08 \\
34.27\end{array}$ & 7.97 & $\begin{array}{l}8.08 \\
8.23\end{array}$ & 0.28 & 0.26 & 36.42 & 36.43 & 0.217 & 0.239 \\
\hline $\mathrm{B}_{6} \mathrm{O}_{8} \mathrm{~T}_{3}^{\prime} \mathrm{D}_{76} \mathrm{D}_{19}^{\mathrm{vi}} \mathrm{M}_{11}^{\prime}$ & 8,576 & 1,850 & 4,160 & 2.25 & 34.31 & $\begin{array}{l}34.58 \\
34.68\end{array}$ & 7.97 & $\begin{array}{l}8.07 \\
8.15\end{array}$ & 0.76 & 0.45 & 35.70 & 36.67 & 0.222 & 0.221 \\
\hline $\mathrm{B}_{6} \mathrm{O}_{11} \mathrm{~T}_{6}^{\prime} \mathrm{D}_{100} \mathrm{D}_{25}^{\mathrm{vi}} \mathrm{M}_{14}^{\prime}$ & 11,318 & 2,310 & 4,780 & 2.07 & 34.28 & $\begin{array}{l}33.92 \\
34.21\end{array}$ & 7.96 & $\begin{array}{l}7.73 \\
7.83\end{array}$ & 0.57 & 0.56 & 35.98 & 36.47 & 0.220 & 0.211 \\
\hline $\mathrm{B}_{6} \mathrm{O}_{14} \mathrm{~T}_{9}^{\prime} \mathrm{D}_{124} \mathrm{D}_{31}^{\mathrm{vi}} \mathrm{M}_{17}^{\prime}$ & 14,059 & 2,910 & 7,190 & 2.47 & 34.26 & $\begin{array}{l}34.18 \\
34.20\end{array}$ & 7.96 & $\begin{array}{l}8.26 \\
8.13\end{array}$ & 0.46 & 0.34 & 36.16 & 35.73 & 0.219 & 0.223 \\
\hline $\mathrm{B}_{9} \mathrm{O}_{14} \mathrm{~T}_{6}^{\prime} \mathrm{D}_{124} \mathrm{D}_{31}^{\mathrm{vi}} \mathrm{M}_{17}^{\prime}$ & 13,962 & 2,820 & 6,880 & 2.44 & 34.24 & $\begin{array}{l}34.08 \\
34.32\end{array}$ & 7.95 & $\begin{array}{l}7.74 \\
7.93\end{array}$ & 0.70 & 0.52 & 35.81 & 36.11 & 0.222 & 0.211 \\
\hline
\end{tabular}

$\% \mathrm{C}, \% \mathrm{H}, \% \mathrm{~B}$, and $\% \mathrm{Si}$ were calculated for predicted molecular formulas of PMVBSs

$D \mathrm{Me}_{2} \mathrm{SiO}, D^{v i} \mathrm{Me}\left(\mathrm{CH}_{2}=\mathrm{CH}\right) \mathrm{SiO}, T^{\prime} \mathrm{MeSi}, M^{\prime} \mathrm{Me}_{3} \mathrm{SiO}$

* \% B was determined by ICP-AES method

** The content of $\mathrm{CH}_{2}=\mathrm{CH}-\mathrm{Si}$ groups was calculated on the basis of integration ratio of their signals to $\mathrm{CH}_{3}-\mathrm{Si}$ signals in the ${ }^{1} \mathrm{H}-\mathrm{NMR}$ and compared with theoretical integration ratios of both signals 
with anhydrous $\mathrm{CaCl}_{2}$, was added $3.34 \mathrm{~g}(0.054 \mathrm{~mol})$ of boric acid (p.a.), $90.25 \mathrm{ml}$ of $\mathrm{Me}_{2} \mathrm{SiCl}_{2}(0.744 \mathrm{~mol}), 30 \mathrm{ml}$ of dry diethyl ether, and a magnetic stirring bar. This mixture of reagents was stirred with a magnetic stirrer for $24 \mathrm{~h}$ at room temperature $\left(24{ }^{\circ} \mathrm{C}\right)$. After this time, stirring was stopped, because the entire amount of boric acid had reacted, giving homogeneous solution of borosiloxane precursor, $\mathrm{B}\left(\mathrm{OSiMe}_{2} \mathrm{Cl}\right)_{3}$, and an excess of $\mathrm{Me}_{2} \mathrm{SiCl}_{2}$. Then, to a fournecked reactor with a volume $1.5 \mathrm{~L}$ (equipped with a mechanical stirrer, thermometer, reflux condenser, and the drying tube filled with anhydrous $\mathrm{CaCl}_{2}$ ) was added the solution of the borosiloxane precursor, $24.14 \mathrm{ml}$ of $\mathrm{MeViSiCl}_{2}(0.186 \mathrm{~mol}), 4.23 \mathrm{ml}$ of $\mathrm{MeSiCl}_{3}(0.036 \mathrm{~mol})$, $12.95 \mathrm{ml} \mathrm{Me} 3 \mathrm{SiCl}(0.102 \mathrm{~mol})$, and $70 \mathrm{ml}$ of dry diethyl ether. The content of reactor was cooled down to $-12{ }^{\circ} \mathrm{C}$ in an ice- $\mathrm{NaCl}$ bath, and $189 \mathrm{ml}$ of pyridine was added dropwise for $70 \mathrm{~min}$., at temperatures ranging from -12 to $-4{ }^{\circ} \mathrm{C}$. Next $34.3 \mathrm{ml}(1.91 \mathrm{~mol})$ of distilled water was added dropwise at temperatures ranging from -9 to $+6{ }^{\circ} \mathrm{C}$ for $200 \mathrm{~min}$. During the addition of water, the reaction system was diluted with $175 \mathrm{ml}$ of dry diethyl ether. The cooling bath was removed, and stirring was continued. When temperature in the reactor reached $13{ }^{\circ} \mathrm{C}$, a vigorous increase of temperature was observed (up to $19^{\circ} \mathrm{C}$ ), and immediately the cooling bath was applied again for $15 \mathrm{~min}$.

In order to block any unreacted terminal $\mathrm{Si}-\mathrm{OH}$ groups, $20.25 \mathrm{ml}$ of trimethylchlorosilane $(0.16 \mathrm{~mol})$ was added, and the content of reactor was stirred for $10 \mathrm{~h}$. On the next day (day 2), the reaction solution was decanted, transferred to a separation funnel, and quickly washed with $25 \mathrm{ml}$ of distilled water. The solution of products was transferred to an Erlenmeyer flask and dried with anhydrous $\mathrm{MgSO}_{4}$. It was kept in a fridge overnight. On the next day (day 3), the solution of products was filtered off through Schott funnel (G-3), and the precipitate was washed with dry diethyl ether. The solvent was distilled off through fractionation Vigreux column. Traces of ether were removed under reduced pressure $(\sim 30 \mathrm{mmHg})$. The obtained product was evacuated at $5 \mathrm{mmHg}$ in oil bath at a temperature $150{ }^{\circ} \mathrm{C}$, giving $46.07 \mathrm{~g}$ of PMVBSs (with yield $59.7 \mathrm{wt} \%$ ) as a colorless liquid with dynamic viscosity of $32.3 \mathrm{cP}$.

Other PMVBSs products were similarly prepared.

\section{Methods}

The FTIR spectra were registered on Bio-Rad 175C spectrophotometer for neat samples, placed between $\mathrm{NaCl}$ plates.

${ }^{1} \mathrm{H}-{ }^{29} \mathrm{Si}-$, and ${ }^{11} \mathrm{~B}-\mathrm{NMR}$ spectra (in $\mathrm{C}_{6} \mathrm{D}_{6}$ ) were recorded on Bruker DRX 500 machine, at the Centre of Molecular and Macromolecular Studies, Polish Academy of Sciences, in Łódź (CBMM PAN). Hexamethyldisiloxane $\mathrm{Me}_{3} \mathrm{SiOSiMe}_{3}$ was used as an external standard in the ${ }^{29} \mathrm{Si}$-NMR (INEPT) $\left(\delta=6.98 \mathrm{ppm}\right.$, in $\left.\mathrm{CDCl}_{3}\right)$.

Elementary analysis $(\% \mathrm{H}$ and $\% \mathrm{C})$ was performed at CBMM PAN. The content of $\mathrm{Si}$ was determined by the "wet method" with concentrated $\mathrm{H}_{2} \mathrm{SO}_{4}$ (p.a.) [16]. The contents of $\mathrm{CH}_{2}=\mathrm{CH}-\mathrm{Si}$ groups were calculated from the integration of signals of $\mathrm{CH}_{2}=\mathrm{CH}-\mathrm{Si}$ and $\mathrm{CH}_{3}-\mathrm{Si}$ in the ${ }^{1} \mathrm{H}-\mathrm{NMR}$ spectra and compared with theoretical integration ratios of both signals. The content of boron was determined by the emission atomic spectroscopy combined with inductive plasma (ICP-AES) in Thermo Jarrell Ash Spectrometer (USA). The calibration of the spectrometer was done with an ICP multi-element standard solution VI for ICP-MS (Merck). Samples for the analysis were dissolved in concentrated acid solutions of spectral grade $\left(\mathrm{HNO}_{3}\right.$ and $\mathrm{H}_{2} \mathrm{SO}_{4}$ ) in an MLS 1200 device (Milestone, Italy), with the application of microwaves.

Dynamic viscosities $\left(\eta^{25}\right)$ of PMVBSs were measured at $25.0^{\circ} \mathrm{C}$ on Brookfield cone-plate reoviscometer HBDV$\mathrm{II}+\mathrm{cP}$ with a cone $\mathrm{cP} 40$ (Table 2). Because of Newtonian properties of PMVBSs, values of rotational speeds are not given.

The molecular weights (MWs) values of PMVBSs and their polydispersities were analyzed using a size exclusion chromatography (SEC) in toluene solution, using LDC analytic chromatograph equipped with refractoMonitor and two phenogel columns covering the MWs values in the range of $10^{2}-$ $10^{5} \mathrm{~g} \mathrm{~mol}^{-1}$. A calibration was made as per polystyrene standards.

The thermal analysis of PMVBSs under air atmosphere was conducted in Paulik Paulik, Erdey derivatograph within the temperature ranging from 25 to $800{ }^{\circ} \mathrm{C}$. Samples weighing $90 \mathrm{mg}$ each were used. The heating rate was $7.9^{\circ} \mathrm{C} / \mathrm{min}$. The thermal analysis under nitrogen was carried out by the method of scanning dynamic calorimetry and thermogravimetry by means of a DSC-204 microcalorimeter of Netzsch and a TG 209 thermobalance of

Table 2 Yields of PMVBSs, their dynamic viscosities, and chemical shifts in ${ }^{11} \mathrm{~B}-\mathrm{NMR}$ spectra

\begin{tabular}{llll}
\hline $\begin{array}{l}\text { Average compositions } \\
\text { of PMVBSs (the expected } \\
\text { structures) }\end{array}$ & Yields/wt\% & $\begin{array}{l}\text { Dynamic } \\
\text { viscosities/cP }\end{array}$ & $\begin{array}{l}{ }^{11} \mathrm{~B}-\mathrm{NMR} \\
\text { data } \\
\delta / \mathrm{ppm}\end{array}$ \\
\hline $\mathrm{B}_{3} \mathrm{O}_{2} \mathrm{D}_{190} \mathrm{D}_{19}^{\mathrm{vi}} \mathrm{M}_{5}$ & 74 & 28.3 & 15.0 \\
$\mathrm{~B}_{6} \mathrm{O}_{5} \mathrm{D}_{180} \mathrm{D}_{10}^{\mathrm{vi}} \mathrm{M}_{8}$ & 75 & 25.8 & 17.2 \\
$\mathrm{~B}_{9} \mathrm{O}_{8} \mathrm{D}_{190} \mathrm{D}_{10}^{\mathrm{vi}} \mathrm{M}_{11}$ & 73 & 16.5 & 17.2 \\
$\mathrm{~B}_{3} \mathrm{O}_{8} \mathrm{~T}_{6}^{\prime}{ }_{6} \mathrm{D}_{76} \mathrm{D}_{19}^{\mathrm{vi}} \mathrm{M}_{11}$ & 67 & 18.4 & 15.3 \\
$\mathrm{~B}_{3} \mathrm{O}_{11} \mathrm{~T}^{\prime}{ }_{9} \mathrm{D}_{100} \mathrm{D}_{25}^{\mathrm{vi}} \mathrm{M}_{14}$ & 58 & 22.4 & 15.0 \\
$\mathrm{~B}_{6} \mathrm{O}_{8} \mathrm{~T}^{\prime}{ }_{3} \mathrm{D}_{76} \mathrm{D}_{19}^{\mathrm{vi}} \mathrm{M}_{11}$ & 60 & 32.3 & 15.0 \\
$\mathrm{~B}_{6} \mathrm{O}_{11} \mathrm{~T}_{6}^{\prime}{ }_{6} \mathrm{D}_{100} \mathrm{D}_{25}^{\mathrm{vi}} \mathrm{M}_{14}$ & 63 & 30.4 & 17.4 \\
$\mathrm{~B}_{6} \mathrm{O}_{14} \mathrm{~T}^{\prime}{ }_{9} \mathrm{D}_{124} \mathrm{D}_{31}^{\mathrm{vi}} \mathrm{M}_{17}$ & 69 & 32.9 & 15.2 \\
$\mathrm{~B}_{9} \mathrm{O}_{14} \mathrm{~T}^{\prime}{ }_{6} \mathrm{D}_{124} \mathrm{D}_{31}^{\mathrm{vi}} \mathrm{M}_{17}$ & 60 & 34.2 & 17.3 \\
\hline
\end{tabular}


Netzsch, using weighed samples of 5-6 mg. The heating rate was $10^{\circ} \mathrm{C} / \mathrm{min}$. DSC curves were recorded for the temperatures ranging from -150 to $500{ }^{\circ} \mathrm{C}$ and $\mathrm{TG}$ curves under nitrogen atmosphere-for the temperature range of $20-500{ }^{\circ} \mathrm{C}$.

\section{Results and discussion}

The prepared branched PMVBSs (with yields: 55-74 \%, Table 2) contain linkages $\mathrm{Si}-\mathrm{O}-\mathrm{Si}$; functional vinylsiloxane groups, $-\left(\mathrm{CH}_{2}=\mathrm{CH}\right) \mathrm{Si}(\mathrm{Me})-\mathrm{O}-$; trifunctional branching points, $\mathrm{BO}_{3 / 2}$; and non-reactive trimethylsiloxane end groups, $\mathrm{Me}_{3} \mathrm{SiO}_{1 / 2}$. Some PMVBSs contain methylsiloxane branching points, $\mathrm{CH}_{3} \mathrm{SiO}_{3 / 2}(T)$, but all the prepared PMVBSs do not have hydroxyl functional groups, $\mathrm{B}-\mathrm{OH}$ and $\mathrm{Si}-\mathrm{OH}$, and also do not have sensitive to hydrolysis linkages $\mathrm{B}-\mathrm{O}-\mathrm{B}$.

The chemical structure of PMVBSs was first analyzed by elemental analysis ( $\% \mathrm{C}, \% \mathrm{H}, \% \mathrm{Si}$, and $\% \mathrm{~B})$ and infrared spectroscopy (Fig. 1).

The absorption bands corresponding to vibrations of the following groups of atoms: $\mathrm{Si}-\mathrm{CH}_{3}(2967,2911,1416,1261$, 845 , and $\left.721 \mathrm{~cm}^{-1}\right)$, Si-C $\left(895 \mathrm{~cm}^{-1}\right)$, Si $\left(\mathrm{CH}_{3}\right)_{3}$ $\left(769 \mathrm{~cm}^{-1}\right), \mathrm{Si}-\mathrm{O}-\mathrm{Si}\left(1,075-1,009 \mathrm{~cm}^{-1}\right)$, and $\mathrm{Si}-\mathrm{CH}=\mathrm{CH}_{2}$ (3048, 3007, 1600, 1410, 1275, 970, and $770 \mathrm{~cm}^{-1}$ ) were present in the FTIR spectra of all the PMVBSs. The absorption bands at $1340 \mathrm{~cm}^{-1}$ correspond to the stretching vibrations of $\mathrm{B}-\mathrm{O}$ bond in the $\mathrm{Si}-\mathrm{O}-\mathrm{B}$ linkages (according to the literature data: $1500-1300 \mathrm{~cm}^{-1}$ ). Characteristic absorption bands of B-O-Si linkages at frequencies of 892 and $675 \mathrm{~cm}^{-1}$ overlap with absorption bands of other linkages, existing in the structure of the PMVBSs. The IR data for PMVBSs were consistent with the literature data [3, 17-21].

The chemical structure of the PMVBSs was confirmed by ${ }^{1} \mathrm{H}-,{ }^{29} \mathrm{Si}-,{ }^{11} \mathrm{~B}-\mathrm{NMR}$ methods . In the ${ }^{1} \mathrm{H}-\mathrm{NMR}$ spectra of PMVBSs (e.g., Fig. 2) were present the following signals of hydrogen atoms: for groups $\mathrm{Si}-\mathrm{CH}_{3}$-in the range $\delta$ : 0.14-0.00 ppm; and for $\mathrm{Si}-\mathrm{CH}=\mathrm{CH}_{2}$ groups in mers $\mathrm{D}^{\mathrm{vi}}$ $\left(\mathrm{D}^{\mathrm{vi}}=\mathrm{MeViSiO}\right.$ )—at $\delta \sim 6 \mathrm{ppm}$; these signals (overlapped multiplets) come from hydrogen atoms of vinyl groups $\mathrm{CH}=\mathrm{CH}_{2}$ (integration 1:2); the higher signal corresponds to protons of $\mathrm{CH}_{2}$ group, and the lower one- to proton of $\mathrm{C}-\mathrm{H}$ bond of the vinyl group.

In the ${ }^{29} \mathrm{Si}-\mathrm{NMR}$ spectra (e.g., Fig. 3) are present signals of silicon atoms of all units present in the structures of these copolymers: $\mathrm{Me}_{3} \mathrm{SiO}_{0.5}(\delta 8.4 \div 7.2 \mathrm{ppm}), \mathrm{Me}_{2} \mathrm{SiO}$ $(\delta-17.8 \div-23 \mathrm{ppm}), \mathrm{MeViSiO}(\delta \sim-35 \mathrm{ppm})$, and $\mathrm{MeSiO}_{1.5}(\delta-62 \div-67 \mathrm{ppm})$. More detailed analysis, of the ${ }^{1} \mathrm{H}-\mathrm{NMR}$ and ${ }^{29} \mathrm{Si}-\mathrm{NMR}$ spectra, and a very complex microstructure of siloxane chain of randomly branched PMVBSs, is discussed elsewhere [15]. PMVBSs may have many sequences of the siloxane chain. Their tacticity depends on the stoichiometry of monomers, the presence of different structural units, the steric hindrance at silicon atoms, and the reaction conditions [15].

The studies by ${ }^{11}$ B-NMR (e.g., Fig. 4) confirmed the presence of boron atoms in the structures of PMVBSs.

Dynamic viscosities $\left(\eta^{25}\right)$ of the PMVBSs (Table 2), measured at $25.0{ }^{\circ} \mathrm{C}$ in Brookfield cone-plate reoviscometer, were quite low and ranged from 16 to $34 \mathrm{cP}$. Low viscosities of PMVBSs in comparison with linear polysiloxanes having similar $M_{\mathrm{w}}$ presumably result from a globular structure of hyperbranched macromolecules.

The values of number average molecular weights $\left(M_{n}\right)$, determined by the SEC method, are significantly lower than those of the calculated $M_{\mathrm{w}}\left(M_{\text {calc }}\right)$ for the predicted molecular formulas of the PMVBSs (Table 1). Taking into consideration the branched structures of the PMVBSs, we presume that their hydrodynamic volumes are much different from hydrodynamic volumes of polystyrene standards, and this seems to be the main reason responsible for lower $M_{n}$ values, than expected. In our opinion, interactions of boron atoms with oxygen atom of the siloxane chains strongly affect the formation of globular structures by PMVBSs.

It is commonly known from the literature that dendrimers and hyperbranched polymers have low viscosities in solution and in melt. Their viscosities and $M_{\mathrm{w}}$ are much lower than those for linear analogs and depend on degree of branching, the polarity of the solvent, the kind of functional
Fig. 1 FTIR spectrum of $\mathrm{B}_{6} \mathrm{O}_{11} \mathrm{~T}_{6}^{\prime} \mathrm{D}_{100} \mathrm{D}_{25}^{\mathrm{vi}} \mathrm{M}^{\prime}{ }_{14}$ (neat)

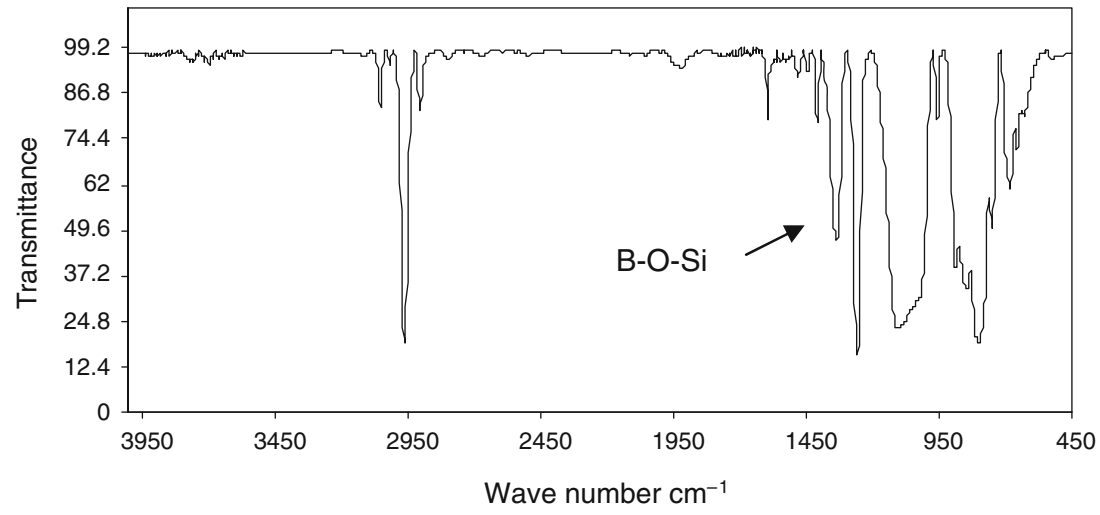


Fig. $2{ }^{1} \mathrm{H}-\mathrm{NMR}$ spectrum of $\mathrm{B}_{6} \mathrm{O}_{5} \mathrm{~T}_{6}^{\prime} \mathrm{D}_{100} \mathrm{D}_{25}^{\mathrm{vi}} \mathrm{M}_{14}^{\prime}$ (in $\mathrm{C}_{6} \mathrm{D}_{6}$ )

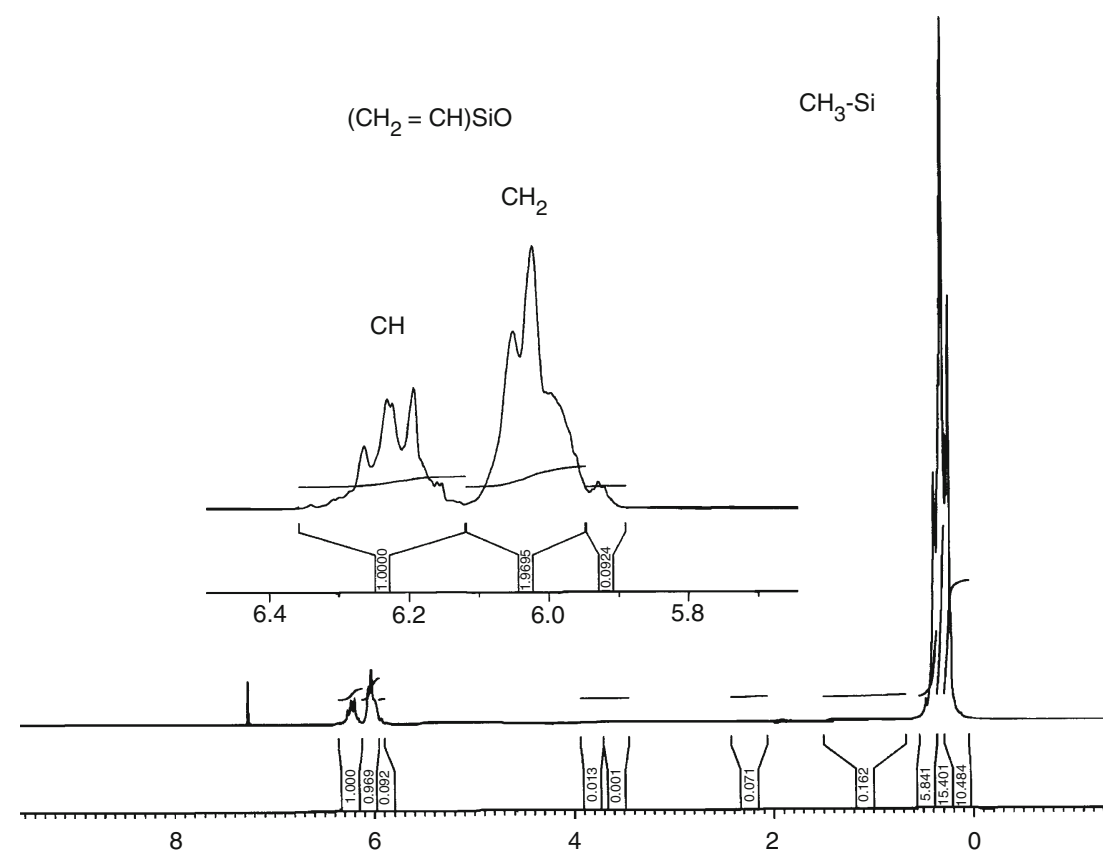

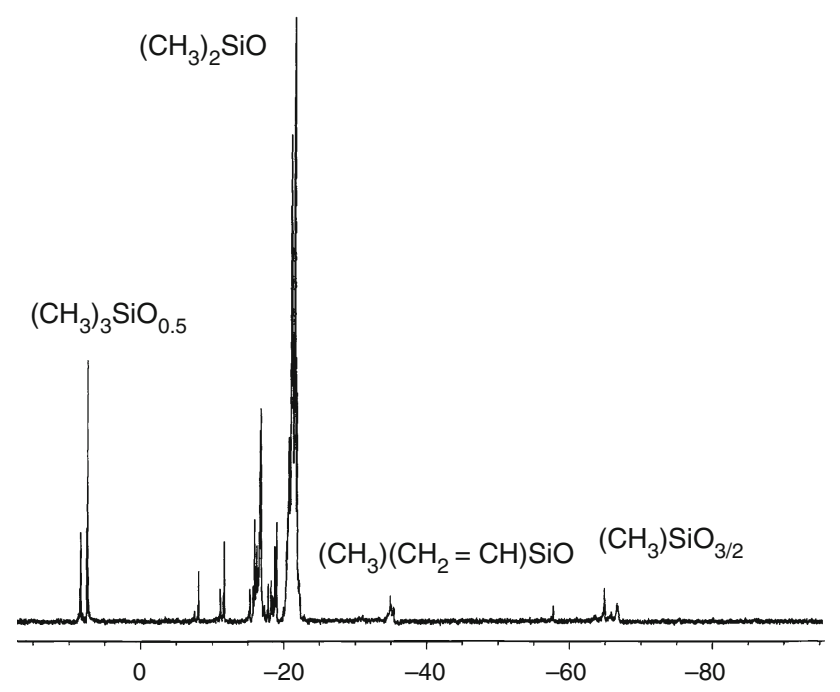

Fig. $3{ }^{29} \mathrm{Si}-\mathrm{NMR}$ spectrum of $\mathrm{B}_{6} \mathrm{O}_{5} \mathrm{~T}_{6}^{\prime} \mathrm{D}_{100} \mathrm{D}_{25}^{\mathrm{vi}} \mathrm{M}^{\prime}{ }_{14}$ (in $\mathrm{C}_{6} \mathrm{D}_{6}$ )

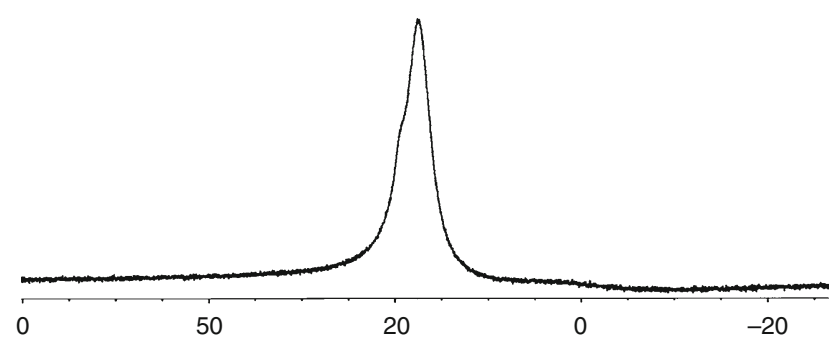

Fig. $4{ }^{11} \mathrm{~B}-\mathrm{NMR}$ spectrum of $\mathrm{B}_{6} \mathrm{O}_{5} \mathrm{~T}^{\prime}{ }_{6} \mathrm{D}_{100} \mathrm{D}_{25}^{\mathrm{vi}} \mathrm{M}^{\prime}{ }_{14}\left(\right.$ in $\mathrm{C}_{6} \mathrm{D}_{6}$ )

groups on their "surface," as well as on the $\mathrm{pH}$ value of a polymer solution. Dendritic and hyperbranched polymers have varying hydrodynamic radii depending on the property of solvents, and they are smaller than those of their linear analogs with the same molar mass. The MWs of of dendrimers and hyperbranched polymers determined by SEC using polystyrene standards are regarded with some skepticism. The hydrodynamic radii were also susceptible to the polarity of functional groups on the periphery [2224]. Values of number average molecular weights $M_{n}$ and weight average molecular weights $M_{\mathrm{w}}$ determined by the SEC method as per polystyrene standards for hyperbranched polysiloxanes were much lower than the MWs values obtained by means of MALLS detectors [25-27].

Polydispersity of $M_{\mathrm{w}}$ (expressed by the ratio: $M_{\mathrm{w}} / M_{n}$ ) is quite broad and similar for all PMVBSs and changes from 2.0 (for $\mathrm{B}_{3} \mathrm{O}_{11} \mathrm{~T}_{9}^{\prime} \mathrm{D}_{100} \mathrm{D}_{25}^{\mathrm{vi}} \mathrm{M}^{\prime}{ }_{14}$ ) to 2.5 (for $\mathrm{B}_{6} \mathrm{O}_{14} \mathrm{~T}_{9}^{\prime} \mathrm{D}_{124} \mathrm{D}_{31}^{\mathrm{vi}} \mathrm{M}^{\prime}{ }_{17}$ ). Results of the determinations of MWs (by SEC method), elemental analysis, and the contents of functional groups $\mathrm{Si}-\mathrm{Vi}$ [mol/100 g] are presented in Table 1.

Polysiloxanes have a good thermal stability [28-32] which mainly depends on their chemical structure: for instance, the contents of phenyl groups promote improved thermal stabilities of poly(dimethyl diphenyl)siloxanes [33]. The addition of silsesquioxanes caused an improvement in the thermal stabilities of other polymers, e.g., epoxy resins [34].

The thermal decomposition of the studied branched PMVBSs under air atmosphere begins at $T=100{ }^{\circ} \mathrm{C}$ and occurs in two stages. As can be seen from derivatographic analysis of the PMVBSs, the characteristics of their thermal transitions are similar, and independent of the boron content (Figs. 5, 6). The results of thermogravimetric analysis under air atmosphere (Table 3) show that the thermal stabilities of the branched PMVBSs determined by the indicator $T_{5}$ are quite similar and range from 140 to 


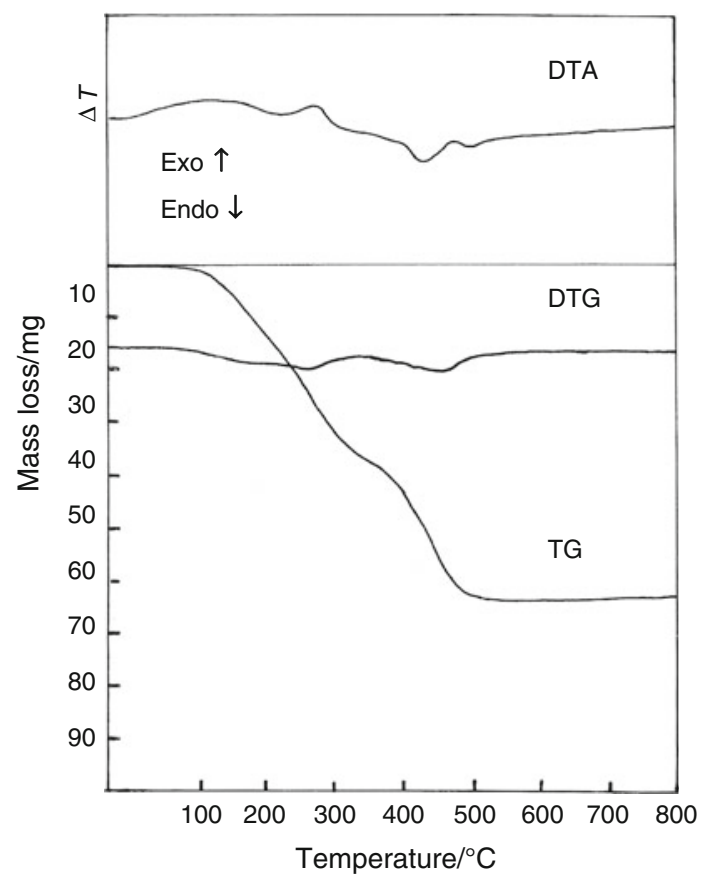

Fig. 5 TG, DTG, and DTA curves of polymethylvinylborosiloxane, $\mathrm{B}_{3} \mathrm{O}_{2} \mathrm{D}_{190} \mathrm{D}_{19}^{\mathrm{vi}} \mathrm{M}_{5}$, under air atmosphere

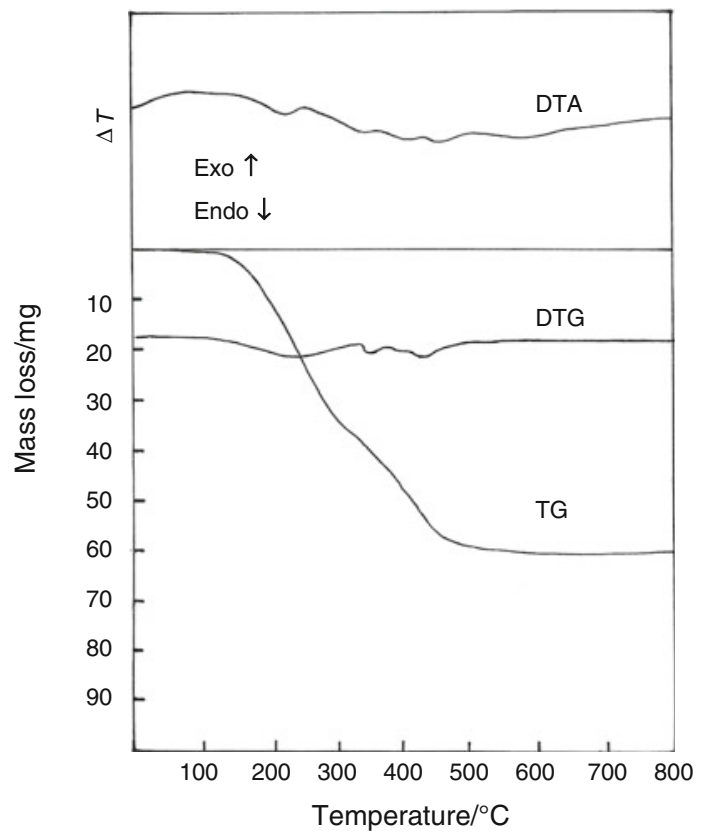

Fig. 6 TG, DTG, and DTA curves of polymethylvinylborosiloxane, $\mathrm{B}_{6} \mathrm{O}_{11} \mathrm{~T}_{6} \mathrm{D}_{100} \mathrm{D}_{25}^{\mathrm{vi}} \mathrm{M}_{14}$, under air atmosphere

$180{ }^{\circ} \mathrm{C}$, while their thermal stabilities determined using the indicator $T_{50}$ are distinctly differentiated for the PMVBSs having different molecular formulas $\left(250-405{ }^{\circ} \mathrm{C}\right.$, Fig. 7).

The PMVBSs: $\mathrm{B}_{6} \mathrm{O}_{5} \mathrm{D}_{180} \mathrm{D}_{10}^{\mathrm{vi}} \mathrm{M}_{8}$ and $\mathrm{B}_{9} \mathrm{O}_{8} \mathrm{D}_{190} \mathrm{D}_{10}^{\mathrm{vi}} \mathrm{M}_{11}$ exhibit the highest thermal stability, determined by the indicators $T_{5}: 180$ and $170{ }^{\circ} \mathrm{C}$, respectively (Table 3 ). The highest value of $T_{50}\left(405{ }^{\circ} \mathrm{C}\right)$ shows PMVBSs with the chemical structure $\mathrm{B}_{3} \mathrm{O}_{2} \mathrm{D}_{190} \mathrm{D}_{19}^{\mathrm{vi}} \mathrm{M}_{5}$ (Table 3; Fig. 7).

It is worthy to stress that quite a large residue after thermooxidative decomposition of PMVBSs $\left(P_{800}\right)$ ranged from 22.2 to $33.3 \%$, and it might be the result of the formation of a ceramic material (a ceramics of a type SiBCO [20, 35-37]—a borosilicate glass and silica). The content of boron in macromolecules of PMVBSs does not affect the mass of the residue after thermooxidative decomposition of the samples; however, the largest mass of the residue characterizes the sample corresponding to the molecular formula of $\mathrm{B}_{6} \mathrm{O}_{11} \mathrm{~T}_{6}^{\prime}{ }_{6} \mathrm{D}_{100} \mathrm{D}_{25}^{\mathrm{vi}} \mathrm{M}_{14}$, with the highest content of boron in the siloxane chain (Table 3 ).

A comparative analysis of the results from Table 3 leads to a conclusion that both the content of boron and a length of the siloxane chain may affect the thermal stability of a PMVBSs (Fig. 7). The thermal stabilities of the studied PMVBSs, as determined by the indicator, $T_{5}$, are not straight dependent on the boron content (which was analyzed by ICP-AES method) (Fig. 7). The highest thermal stability $\left(T_{5}=180{ }^{\circ} \mathrm{C}\right)$ shows PMVBSs of the chemical structure $\mathrm{B}_{6} \mathrm{O}_{5} \mathrm{D}_{180} \mathrm{D}_{10}^{\mathrm{vi}} \mathrm{M}_{8}\left(\mathrm{~B}_{6} \mathrm{D}_{180}\right)$ with the content of boron being only $0.31 \mathrm{wt} \%$, having the long siloxane chains, i.e., $14-15$ siloxane units ( $\mathrm{D}$ and $\mathrm{D}^{\mathrm{vi}}$ ) between boron atoms. On the other hand, the lowest thermal stability $\left(T_{5}=140{ }^{\circ} \mathrm{C}\right)$ have two PMVBSs with the same functionality $\left(\mathrm{D}_{19}^{\mathrm{vi}}\right): \quad \mathrm{B}_{3} \mathrm{O}_{8} \mathrm{~T}_{6}^{\prime}{ }_{6} \mathrm{D}_{76} \mathrm{D}_{19}^{\mathrm{vi}} \mathrm{M}_{11} \quad\left(\mathrm{~B}_{3} \mathrm{~T}_{6}\right) \quad$ and $\mathrm{B}_{3} \mathrm{O}_{2} \mathrm{D}_{190} \mathrm{D}_{19}^{\mathrm{vi}} \mathrm{M}_{5}\left(\mathrm{~B}_{3}\right)$, with the lower contents of boron among the discussed PMVBSs $(0.27$ and $0.17 \mathrm{wt} \%$, respectively) and with the different lengths of the siloxane chains (5 and $\sim 30$ siloxane units, respectively) between branching points (boron atoms and $\mathrm{MeSiO}_{1.5}$ units) (Table 3; Fig. 7).

The increase of the thermal stability with the increasing boron content, as determined by the indicator $T_{50}$, was also observed-in the following order of PMVBSs: $\mathrm{B}_{3} \mathrm{O}_{11} \mathrm{~T}^{\prime}{ }_{9}$ $\mathrm{D}_{100} \mathrm{D}_{25}^{\mathrm{vi}} \mathrm{M}_{14}, \quad \mathrm{~B}_{3} \mathrm{O}_{8} \mathrm{~T}^{\prime}{ }_{6} \mathrm{D}_{76} \mathrm{D}_{19}^{\mathrm{vi}} \mathrm{M}_{11}, \quad \mathrm{~B}_{6} \mathrm{O}_{14} \mathrm{~T}^{\prime}{ }_{9} \mathrm{D}_{124} \mathrm{D}_{31}^{\mathrm{vi}} \mathrm{M}_{17}$, $\mathrm{B}_{6} \mathrm{O}_{8} \mathrm{~T}_{3}^{\prime} \mathrm{D}_{76} \mathrm{D}_{19}^{\mathrm{vi}} \mathrm{M}_{11}, \mathrm{~B}_{9} \mathrm{O}_{14} \mathrm{~T}_{6}^{\prime} \mathrm{D}_{124} \mathrm{D}_{31}^{\mathrm{vi}} \mathrm{M}_{17}$, and $\mathrm{B}_{6} \mathrm{O}_{11} \mathrm{~T}_{6}^{\prime}$ $\mathrm{D}_{100} \mathrm{D}_{25}^{\mathrm{vi}} \mathrm{M}_{14}$. Unexpectedly, the highest thermal stability, as determined by the indicator $T_{50}$, was found for the PMVBSs with the predicted chemical structure $\mathrm{B}_{3} \mathrm{O}_{2}$ $\mathrm{D}_{190} \mathrm{D}_{19}^{\mathrm{vi}} \mathrm{M}_{5}$, with the lowest content of boron $(0.17 \mathrm{wt} \%)$, and long siloxane chains between boron atoms, were in the order of the PMVBSs: $\mathrm{B}_{9} \mathrm{O}_{8} \mathrm{D}_{190} \mathrm{D}_{10}^{\mathrm{vi}} \mathrm{M}_{11}, \mathrm{~B}_{6} \mathrm{O}_{5} \mathrm{D}_{180} \mathrm{D}_{10}^{\mathrm{vi}} \mathrm{M}_{8}$, and $\mathrm{B}_{3} \mathrm{O}_{2} \mathrm{D}_{190} \mathrm{D}_{19}^{\mathrm{vi}} \mathrm{M}_{5}$ the $T_{50}$ values $\left(332,340\right.$, and $405{ }^{\circ} \mathrm{C}$, respectively) increased with the growing length of siloxane chains between boron atoms $(\sim 22, \sim 32$, and $\sim 30$ siloxane units, respectively). The highest value of $T_{50}$ $\left(405{ }^{\circ} \mathrm{C}\right.$ ) obtained for $\mathrm{B}_{3} \mathrm{O}_{2} \mathrm{D}_{190} \mathrm{D}_{19}^{\mathrm{vi}} \mathrm{M}_{5}$ may have resulted from the higher content of vinyl groups, in comparison with $\mathrm{B}_{9} \mathrm{O}_{8} \mathrm{D}_{190} \mathrm{D}_{10}^{\mathrm{vi}} \mathrm{M}_{11}$ and $\mathrm{B}_{6} \mathrm{O}_{5} \mathrm{D}_{180} \mathrm{D}_{10}^{\mathrm{vi}} \mathrm{M}_{8}$. It seems that, for these three PMVBSs, the content of boron does not affect $T_{50}$ values.

On the basis of the obtained results, it can be stated that the thermal stability of the synthesized branched PMVBSs 
Table 3 Results of derivatographic analysis of polymethylvinylborosiloxanes under air atmosphere

\begin{tabular}{|c|c|c|c|c|c|c|c|}
\hline No. & $\begin{array}{l}\text { Predicted average } \\
\text { composition of PMVBSs }\end{array}$ & $\begin{array}{l}\text { Sample } \\
\text { abbrev. }\end{array}$ & $T_{5} /{ }^{\circ} \mathrm{C}$ & $T_{50} /{ }^{\circ} \mathrm{C}$ & $P_{800} / \%$ & $\begin{array}{l}\% \text { B } \\
\text { Found }\end{array}$ & $\begin{array}{l}\text { Vi groups } / \mathrm{mol} / 100 \mathrm{~g} \\
\text { Found }\end{array}$ \\
\hline 1 & $\mathrm{~B}_{3} \mathrm{O}_{8} \mathrm{~T}_{6}^{\prime} \mathrm{D}_{76} \mathrm{D}_{19}^{\mathrm{vi}} \mathrm{M}_{11}$ & $\mathrm{~B}_{3} \mathrm{~T}_{6}$ & 140 & 250 & 25.0 & 0.27 & 0.240 \\
\hline 2 & $\mathrm{~B}_{3} \mathrm{O}_{11} \mathrm{~T}^{\prime}{ }_{9} \mathrm{D}_{100} \mathrm{D}_{25}^{\mathrm{vi}} \mathrm{M}_{14}$ & $\mathrm{~B}_{3} \mathrm{~T}_{9}$ & 151 & 252 & 22.2 & 0.26 & 0.239 \\
\hline 3 & $\mathrm{~B}_{6} \mathrm{O}_{11} \mathrm{~T}_{6}^{\prime}{ }_{6} \mathrm{D}_{100} \mathrm{D}_{25}^{\mathrm{vi}} \mathrm{M}_{14}$ & $\mathrm{~B}_{6} \mathrm{~T}_{6}$ & 161 & 375 & 33.3 & 0.56 & 0.211 \\
\hline 4 & $\mathrm{~B}_{6} \mathrm{O}_{14} \mathrm{~T}_{9}^{\prime}{ }_{9} \mathrm{D}_{124} \mathrm{D}_{31}^{\mathrm{vi}} \mathrm{M}_{17}$ & $\mathrm{~B}_{6} \mathrm{~T}_{9}$ & 150 & 250 & 22.2 & 0.34 & 0.223 \\
\hline 5 & $\mathrm{~B}_{6} \mathrm{O}_{8} \mathrm{~T}_{3}^{\prime} \mathrm{D}_{76} \mathrm{D}_{19}^{\mathrm{vi}} \mathrm{M}_{11}$ & $\mathrm{~B}_{6} \mathrm{~T}_{3}$ & 152 & 275 & 24.4 & 0.45 & 0.221 \\
\hline 6 & $\mathrm{~B}_{9} \mathrm{O}_{14} \mathrm{~T}_{6}^{\prime}{ }^{\prime} \mathrm{D}_{124} \mathrm{D}_{31}^{\mathrm{vi}} \mathrm{M}_{17}$ & $\mathrm{~B}_{9} \mathrm{~T}_{6}$ & 150 & 285 & 27.8 & 0.52 & 0.211 \\
\hline 7 & $\mathrm{~B}_{3} \mathrm{O}_{2} \mathrm{D}_{190} \mathrm{D}_{19}^{\mathrm{vi}} \mathrm{M}_{5}$ & $\mathrm{~B}_{3} \mathrm{D}_{190}$ & 140 & 405 & 28.9 & 0.17 & 0.107 \\
\hline 8 & $\mathrm{~B}_{6} \mathrm{O}_{5} \mathrm{D}_{180} \mathrm{D}_{10}^{\mathrm{vi}} \mathrm{M}_{8}$ & $\mathrm{~B}_{6} \mathrm{D}_{180}$ & 180 & 340 & 26.9 & 0.31 & 0.063 \\
\hline 9 & $\mathrm{~B}_{9} \mathrm{O}_{8} \mathrm{D}_{190} \mathrm{D}_{10}^{\mathrm{vi}} \mathrm{M}_{11}$ & $\mathrm{~B}_{9} \mathrm{D}_{190}$ & 170 & 332 & 24.7 & 0.46 & 0.062 \\
\hline
\end{tabular}

$T_{5}$ and $T_{50}$ temperature of 5 and $50 \%$ of sample mass loss, respectively

$P_{800}$ residue after heating of a sample up to $800{ }^{\circ} \mathrm{C}$

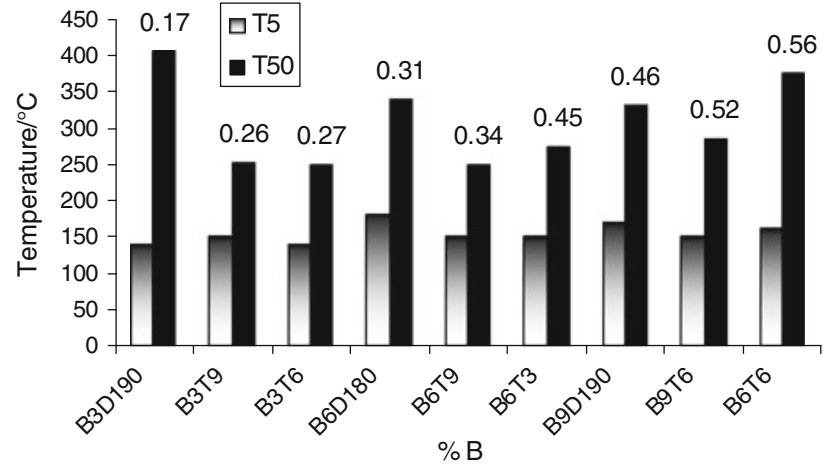

Fig. 7 The thermal stability of polymethylvinyloborosiloxanes with the different boron content, under air atmosphere, determined by the indicators $T_{5}$ and $T_{50}$

is affected not only by the content of boron, but also by their chemical structure: degree of branching (3-15) [i.e., the number of boron atoms and methylsiloxane units
$\mathrm{MeSiO}_{3 / 2}(T)$ in macromolecules]; their functionalities (the number of vinylsiloxane groups in the molecule); andvery likely - the length of the siloxane segments between branching points, which is the same for most of the studied PMVBSs $\left(\left[\mathrm{Me}_{2} \mathrm{SiO}\right] /[\mathrm{MeViSiO}]=4\right)$, except for those with three structures: $\mathrm{B}_{3} \mathrm{O}_{2} \mathrm{D}_{190} \mathrm{D}_{19}^{\mathrm{vi}} \mathrm{M}_{5}, \mathrm{~B}_{6} \mathrm{O}_{5} \mathrm{D}_{180} \mathrm{D}_{10}^{\mathrm{vi}} \mathrm{M}_{8}$, and $\mathrm{B}_{9} \mathrm{O}_{8} \mathrm{D}_{190} \mathrm{D}_{10}^{\mathrm{vi}} \mathrm{M}_{11}$.

From a comparison of the values, $T_{5}$ and $T_{50}$, we obtain that under air atmosphere PMVBSs characterize lower thermal stabilities than for the polymethylsiloxanes bearing only methyl groups or functional hydrosiloxane or vinylsiloxane groups in macromolecules [38].

The thermal properties of PMVBSs were also studied by the thermogravimetric method under oxygen-free atmosphere. The indicators of the thermal stabilities, $T_{5}$ and $T_{50}$, as determined from TG curves under nitrogen atmosphere, show higher values (Table 4) than those under air atmosphere (Table 3). The thermal decomposition of the PMVBSs under nitrogen atmosphere begins at $T \geq 140{ }^{\circ} \mathrm{C}$,

Table 4 Results of derivatographic analysis of PMVBSs under nitrogen atmosphere

\begin{tabular}{|c|c|c|c|c|c|c|}
\hline $\begin{array}{l}\text { Predicted average } \\
\text { composition of PMVBSs }\end{array}$ & $\begin{array}{l}\text { Sample } \\
\text { abbrev. }\end{array}$ & $T_{5} /{ }^{\circ} \mathrm{C}$ & $T_{50} /{ }^{\circ} \mathrm{C}$ & $P_{500} / \%$ & $\begin{array}{l}\mathrm{wt} \% \text { of } \mathrm{B} \\
\text { Found }\end{array}$ & $\begin{array}{l}\text { Vi groups/mol/100 g } \\
\text { Found }\end{array}$ \\
\hline $\mathrm{B}_{3} \mathrm{O}_{8} \mathrm{~T}_{6}^{\prime} \mathrm{D}_{76} \mathrm{D}_{19}^{\mathrm{vi}} \mathrm{M}_{11}$ & $\mathrm{~B}_{3} \mathrm{~T}_{6}$ & 156 & 304 & 13.5 & 0.27 & 0.240 \\
\hline $\mathrm{B}_{3} \mathrm{O}_{11} \mathrm{~T}_{9}^{\prime} \mathrm{D}_{100} \mathrm{D}_{25}^{\mathrm{vi}} \mathrm{M}_{14}$ & $\mathrm{~B}_{3} \mathrm{~T}_{9}$ & 195 & 358 & 16.5 & 0.26 & 0.239 \\
\hline $\mathrm{B}_{6} \mathrm{O}_{8} \mathrm{~T}_{3}^{\prime} \mathrm{D}_{76} \mathrm{D}_{19}^{\mathrm{vi}} \mathrm{M}_{11}$ & $\mathrm{~B}_{6} \mathrm{~T}_{3}$ & 188 & 385 & 15.0 & 0.45 & 0.211 \\
\hline $\mathrm{B}_{6} \mathrm{O}_{11} \mathrm{~T}_{6}^{\prime} \mathrm{D}_{100} \mathrm{D}_{25}^{\mathrm{vi}} \mathrm{M}_{14}$ & $\mathrm{~B}_{6} \mathrm{~T}_{6}$ & 241 & 438 & 25.5 & 0.56 & 0.223 \\
\hline $\mathrm{B}_{6} \mathrm{O}_{14} \mathrm{~T}_{9}^{\prime} \mathrm{D}_{124} \mathrm{D}_{31}^{\mathrm{vi}} \mathrm{M}_{17}$ & $\mathrm{~B}_{6} \mathrm{~T}_{9}$ & 240 & 427 & 12.5 & 0.34 & 0.221 \\
\hline $\mathrm{B}_{9} \mathrm{O}_{14} \mathrm{~T}_{6}^{\prime} \mathrm{D}_{124} \mathrm{D}_{31}^{\mathrm{vi}} \mathrm{M}_{17}$ & $\mathrm{~B}_{9} \mathrm{~T}_{6}$ & 263 & 412 & 12.5 & 0.52 & 0.211 \\
\hline $\mathrm{B}_{3} \mathrm{O}_{2} \mathrm{D}_{190} \mathrm{D}_{19}^{\mathrm{vi}} \mathrm{M}_{5}$ & $\mathrm{~B}_{3} \mathrm{D}_{190}$ & 230 & 450 & 13.5 & 0.17 & 0.107 \\
\hline $\mathrm{B}_{6} \mathrm{O}_{5} \mathrm{D}_{180} \mathrm{D}_{10}^{\mathrm{vi}} \mathrm{M}_{8}$ & $\mathrm{~B}_{6} \mathrm{D}_{180}$ & 213 & 381 & 10.0 & 0.31 & 0.063 \\
\hline $\mathrm{B}_{9} \mathrm{O}_{8} \mathrm{D}_{190} \mathrm{D}_{10}^{\mathrm{vi}} \mathrm{M}_{11}$ & $\mathrm{~B}_{9} \mathrm{D}_{190}$ & 225 & 398 & 8.0 & 0.46 & 0.062 \\
\hline
\end{tabular}

$T_{5}$ and $T_{50}$ temperature of 5 and $50 \%$ of sample mass loss

$P_{500}$ residue after heating of a sample up to $500{ }^{\circ} \mathrm{C}$ 
which is higher temperature than that under air atmosphere (Figs. 5, 6, 8). The values of the indicators of the thermal stabilities, $T_{5}$ and $T_{50}$, of PMVBSs under nitrogen atmosphere are distinctly higher than those under air atmosphere (Tables 3,4). One may judge that as a result of the heating process of PMVBSs under air atmosphere more volatile products (such as siloxanes, silanes, $\mathrm{CO}_{2}, \mathrm{H}_{2} \mathrm{O}$, and even formaldehyde $\mathrm{CH}_{2} \mathrm{O}$, methanol, and formic acid) are formed [28-34, 38], in comparison with the heating process under nitrogen atmosphere. A liberation of these products promotes ceramization processes: the formation of the ceramics of the type SiBCO [19, 36-38]-a borosilicate glass and silica. Apparently, these processes occur more intensively under air atmosphere than under nitrogen atmosphere, which leads to the distinctly higher value of the residue after thermooxidative decomposition of PMVBSs $\left(P_{800}\right)$, as compared with the residue after thermal decomposition $\left(P_{500}\right)$ (Tables 3,4$)$.

A comparative analysis of the obtained results leads to a conclusion that, regardless of experimental conditions, the content of boron does not affect the systematic influence, both on the indicator $T_{5}$, as well on the $T_{50}$ values of the studied polymers, and on the residue after the thermooxidative destruction $\left(P_{800}=22.2-33.3 \%\right)$ and the thermal destruction $\left(P_{500}=8.0-16.5 \mathrm{wt} \%\right.$, except for $\mathrm{B}_{6} \mathrm{~T}_{6}$ : $P_{500}=25.5 \mathrm{wt} \%$, see: Tables 3, 4). Nevertheless, also under oxygen-free atmosphere, the highest values of the thermal stability and the highest values of the residue after the thermal decomposition showed the branched PMVBSs with the structure, $\mathrm{B}_{6} \mathrm{O}_{11} \mathrm{~T}^{\prime}{ }_{6} \mathrm{D}_{100} \mathrm{D}_{25}^{\mathrm{vi}} \mathrm{M}_{14}$, with the highest content of boron and the quite high content of vinyl groups in macromolecules of the polymer (Table 4).

A rating of thermal properties of studied PMVBSs is quite complicated because of the many differences in their chemical structures:

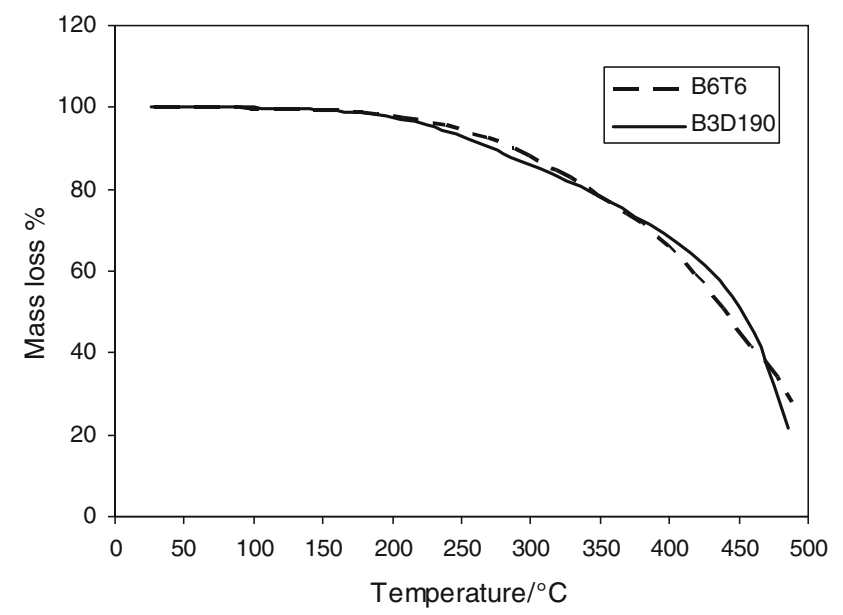

Fig. 8 TG curves of two PMVBSs $\left(\mathrm{B}_{3} \mathrm{O}_{2} \mathrm{D}_{190} \mathrm{D}_{19}^{\mathrm{vi}} \mathrm{M}_{5}\right.$ and $\left.\mathrm{B}_{6} \mathrm{O}_{11} \mathrm{~T}_{6}^{\prime} \mathrm{D}_{100} \mathrm{D}_{25}^{\mathrm{vi}} \mathrm{M}_{14}\right)$ determined under nitrogen atmosphere
(1) The presence of two kinds of branching units (boron atoms and methylsiloxane units $\mathrm{CH}_{3} \mathrm{SiO}_{1.5}$ ),

(2) The different degrees of branching (3-15),

(3) The different contents of boron,

(4) The different values of MWs,

(5) The lengths of the siloxane chains between branching points (boron atoms and $\mathrm{MeSiO}_{1.5}$ units), and

(6) The different functionalities (the contents of vinylsiloxane groups).

We are aware that more detailed studies of thermal stabilities of PMVBSs need to be carried out, with the application of a much wider family of model polymers having very well "tailored" structures.

A characteristic feature of macromolecular compounds is the temperature of transition into a glass state. The temperature of this phase transition determines the thermal resistance of the polymer to an influence of low temperatures. From the analysis of DSC data of the synthesized PMVBSs, it results that their glass transition temperatures $\left(T_{\mathrm{g}}\right)$ are different (Table 5), but they are distinctly lower than those for polydimethylsiloxanes (PDMS). In the case of most PDMS (oils with linear structure and silicon rubbers), the values of $T_{\mathrm{g}}$ are usually close to $-122{ }^{\circ} \mathrm{C}[29,32,39]$. The lowest known value of $T_{\mathrm{g}}$ among polysiloxanes $\left(T_{\mathrm{g}}=-152{ }^{\circ} \mathrm{C}\right)$ was observed for crosslinked polycyclic products of the hydrolytic polycondensation of pentamethylcyclopentasiloxane (MeH$\mathrm{SiO})_{5}$, occurring toward Karstedt catalyst [40]. The lowest value of $T_{\mathrm{g}}$ among PMVBSs $\left(-137{ }^{\circ} \mathrm{C}\right)$, during cooling process, shows $\mathrm{B}_{3} \mathrm{O}_{8} \mathrm{~T}_{6}^{\prime} \mathrm{D}_{76} \mathrm{D}_{19}^{\mathrm{vi}} \mathrm{M}_{11}$ with shorter dimethylsiloxane segments $\left(\left[\mathrm{Me}_{2} \mathrm{SiO}\right] /[\mathrm{MeViSiO}]=4\right)$ present between three branching points $\mathrm{BO}_{3 / 2}$ and six points $\mathrm{MeSiO}_{3 / 2}$, whereas the highest value of $T_{\mathrm{g}}\left(-122^{\circ} \mathrm{C}\right)$ was found for PMVBSs $\mathrm{B}_{3} \mathrm{O}_{2} \mathrm{D}_{190} \mathrm{D}_{19}^{\mathrm{vi}} \mathrm{M}_{5}$ with the longer $\left(\mathrm{Me}_{2} \mathrm{SiO}\right)_{\mathrm{n}}$ segments $\left(\left[\mathrm{Me}_{2} \mathrm{SiO}\right] /[\mathrm{MeViSiO}]=10\right)$ and the low branching degree. This polymer statistically contains only three branching units $\mathrm{BO}_{3 / 2}$ and six branching points $\mathrm{MeSiO}_{3 / 2}$ in the macromolecule (Table 5).

Table 5 Results of DSC analysis of PMVBSs under inert gas atmosphere $\left(\mathrm{N}_{2}\right)$

\begin{tabular}{llll}
\hline & $T_{\mathrm{g}}{ }^{\circ} \mathrm{C}$ & $\begin{array}{l}\text { Temperature range } \\
\text { of glass process }\end{array}$ & $\begin{array}{l}\text { wt\% of } \mathrm{B} \\
\text { (found) }\end{array}$ \\
\hline $\mathrm{B}_{3} \mathrm{O}_{2} \mathrm{D}_{190} \mathrm{D}_{19}^{\mathrm{vi}} \mathrm{M}_{5}$ & -122 & $-128 \div-116$ & 0.17 \\
$\mathrm{~B}_{3} \mathrm{O}_{11} \mathrm{~T}^{\prime}{ }_{9} \mathrm{D}_{100} \mathrm{D}_{25}^{\mathrm{vi}} \mathrm{M}_{14}$ & -124 & $-136 \div-128$ & 0.26 \\
$\mathrm{~B}_{6} \mathrm{O}_{11} \mathrm{~T}^{\prime}{ }_{6} \mathrm{D}_{100} \mathrm{D}_{25}^{\mathrm{vi}} \mathrm{M}_{14}$ & -128 & $-135 \div-121$ & 0.56 \\
$\mathrm{~B}_{6} \mathrm{O}_{14} \mathrm{~T}^{\prime}{ }_{9} \mathrm{D}_{124} \mathrm{D}_{31}^{\mathrm{vi}} \mathrm{M}_{17}$ & -129 & $-132 \div-125$ & 0.34 \\
$\mathrm{~B}_{9} \mathrm{O}_{14} \mathrm{~T}^{\prime}{ }_{6} \mathrm{D}_{124} \mathrm{D}_{31}^{\mathrm{vi}} \mathrm{M}_{17}$ & -126 & $-132 \div-120$ & 0.52 \\
$\mathrm{~B}_{6} \mathrm{O}_{5} \mathrm{D}_{190} \mathrm{D}_{10}^{\mathrm{vi}} \mathrm{M}_{8}$ & -133 & $-137 \div-129$ & 0.31 \\
$\mathrm{~B}_{9} \mathrm{O}_{8} \mathrm{D}_{190} \mathrm{D}_{10}^{\mathrm{vi}} \mathrm{M}_{11}$ & -133 & $-139 \div-128$ & 0.46 \\
$\mathrm{~B}_{6} \mathrm{O}_{8} \mathrm{~T}^{\prime}{ }_{3} \mathrm{D}_{76} \mathrm{D}_{19}^{\mathrm{vi}} \mathrm{M}_{11}$ & -134 & $-140 \div-127$ & 0.45 \\
$\mathrm{~B}_{3} \mathrm{O}_{8} \mathrm{~T}_{6}^{\prime}{ }_{6} \mathrm{D}_{76} \mathrm{D}_{19}^{\mathrm{vi}} \mathrm{M}_{11}$ & -137 & $-145 \div-128$ & 0.27 \\
\hline
\end{tabular}


One may judge that distinct differences of $T_{\mathrm{g}}$ values result from the branched structures and rich structural possibilities of the analyzed PMVBSs, including their tacticity [15]. Space interactions of boron atoms with silicon atoms could also affect the $T_{\mathrm{g}}$ values of the studied PMVBSs.

\section{Conclusions}

1. The residues after the thermooxidative decomposition of branched PMVBSs $\left(P_{800}\right)$ ranged from 22.2 to $33.3 \%$. It results from the formation of the ceramics of the type $\mathrm{SiBCO}$ - the borosilicate glass and silica.

2. The glass temperatures $\left(T_{\mathrm{g}}\right)$ of the branched PMVBSs change from -122 to $-137{ }^{\circ} \mathrm{C}$, depending on their chemical structures, and especially on the lengths of dimethylsiloxane segments, on the contents of boron, and on the degrees of branching of macromolecules. The $T_{\mathrm{g}}$ values of the most PMVBSs are lower than those for PDMS (oils with linear structure and silicone rubbers).

Open Access This article is distributed under the terms of the Creative Commons Attribution License which permits any use, distribution, and reproduction in any medium, provided the original author(s) and the source are credited.

\section{References}

1. Nalwa $\mathrm{H}$, editors. In: Handbook of organic-inorganic hybrid materials and nanocomposites, Hybrid materials; nanocomposites, vol. 1; vol. 2. New York: American Science Publication; 2003.

2. Salamone JC, editor. In: Abe Y, Gunji T, editors. Polymeric materials encyclopedia: polyborosiloxanes, vol. 7. New York: CRC Press; 1996.

3. Wang Q, Fu L, Hu X, Zhang Z, Xie Z. Preparation and properties of borosiloxane gels. J Appl Polym Sci. 2006;99:719-24.

4. Huo Y, Fan Q, Dembsey N, Patra PK. Influence of polyborosiloxane on the flame retardancy of polyethylene terephthalate-clay nanocomposite. Polym Mat. 2007;96:528-30.

5. Anna P, Marosi G, Bourbigot S, Le Bras M, Delobel R. Intumescent flame retardant systems of modified rheology. Polym Degrad Stab. 2002;77:243-7.

6. Lu SY, Hamerton I. Recent developments in the chemistry of halogenfree flame retardant polymers. Prog Polym Sci. 2002;27:1661-712.

7. Rybiński P, Janowska G, Kucharska-Jastrząbek A. Influence of surface modification on thermal stability and flammability of cross-linked rubbers. J Therm Anal Calorim. 2010;100:1037-44.

8. Achilias DS, Nikolaidis AK, Karayannidis GP. PMMA/organomodified montmorillonite nanocomposites prepared by in situ bulk polymerization. J Therm Anal Calorim. 2010;102:451-60.

9. Lalikova S, Pajtasova M, Ondrusova D, Bazylakova T, Olsovsky M, Jona E, Mojumdar SC. J Therm Anal Calorim. 2010;100:745-9.

10. Janowska G, Kucharska-Jastrząbek A, Rybiński P. Thermal stability, flammability and fire hazard of butadiene-acrylonitrile rubber nanocomposites. J Therm Anal Calorim. 2011;103:1039-46.
11. Zhao M, Liu P. Halloysite nanotubes/polystyrene (HNTs/PS) nanocomposites via in situ bulk polymerization. J Therm Anal Calorim. 2008;94:103-7.

12. Rybiński P, Janowska G, Jóźwiak M, Pająk A. Thermal properties and flammability of nanocomposites based on diene rubbers and naturally occurring and activated halloysite nanotubes. J Therm Anal Calorim. 2012;107:1243-9.

13. Chen X, Jiao C, Zhang J. Microencapsulation of ammonium polyphosphate with hydroxyl silicone oil and its flame retardance in thermoplastic polyurethane. J Therm Anal Calorim. 2011;104: 1037-43.

14. Chruściel J, Fejdyś-Kaczmarek M, Michalska Z. New liquid, branched, hybrid poly-(methylvinylborosiloxanes) and method of their preparation. Pat PL. 2011;209514:B1.

15. Chruściel J, Fejdyś M, Fortuniak W. Synthesis and characterization of new, liquid, branched poly(methylvinylborosiloxanes). e-Polymers. 2011 (submitted for publication).

16. Smith AL. Analysis of silicones. Wiley, New York. 1974.

17. Zha C, Atkins GR, Masters AF. A spectroscopic study of an anhydrous tetraethyl orthosilicate-boric acid-ethanol system. J Sol-Gel Sci Technol. 1998;13:103-7.

18. Kaşgöz A, Misono T, Abe Y. Sol-gel preparation of borosilicates. J Non-Cryst Solids. 1999;243:168-74.

19. Soraru GD, Babonneau F, Gervais C, Dallabona N. Hybrid $\mathrm{RSiO}_{1.5} / \mathrm{B}_{2} \mathrm{O}_{3}$ gels from modified silicon alkoxides and boric acid. J Sol-Gel Sci Technol. 2000;18:11-8.

20. Schiavon MA, Gervais C, Babonneau F, Soraru GD. Crystallization behavior of novel silicon boron oxycarbide glasses. J Am Ceram Soc. 2004;87:203-8.

21. Peňa-Alonso R, Rubio J, Rubio F, Oteo JL. Characterisation of the pyrolysis process of boron-containing ormosils by FT-IR analysis. J Anal Appl Pyrolysis. 2004;71:827-45.

22. Morikawa A, Kakimoto M, Imai Y. Synthesis and characterization of new polysiloxane starburst polymers. Macromolecules. 1991;24:3469-74.

23. Chang H-T, Frechet JMJ. Proton-transfer polymerization: a new approach to hyper-branched polymers. J Am Chem Soc. 1999;121:2313-4.

24. Innoue K. Functional dendrimers, hyperbranched and star polymers. Prog Polym Sci. 2000;25:453-571.

25. Paulasaari JK, Weber WP. Synthesis of hyperbranched polysiloxanes by base-catalyzed proton-transfer polymerization. Comparison of hyperbranched polymer microstructure and properties to those of linear analogues prepared by cationic or anionic ring-opening polymerization. Macromolecules. 2000;33: 2005-10.

26. Paulasaari JK, Weber WP. Base catalyzed proton transfer polymerization of 1-hydroxy-pentamethylcyclotrisiloxane. Comparison of hyperbranched polymer microstructure and properties to those of highly regular linear analogs. Macromol Chem Phys. 2000;201:1585-92.

27. Jikei M, Kakimoto M. Hyperbranched polymers: a promising new class of materials. Prog Polym Sci. 2001;26:1233-85.

28. Liptay G, Nagy J, Borbély-Kuszman A, Weis JC. Thermal analysis of silicone caoutchouc polymers and silicone rubbers II. J Therm Anal Calorim. 1987;32:1683-91.

29. Dobkowski Z, Zielecka M. Thermal analysis of the polysiloxanepoly(tetrafluoroethylene) coating system. J Therm Anal Calorim. 2002:68:147-58.

30. Budrugeac P, Racles C, Cozan V, Cazacu M. Thermal and thermooxidative stabilities of some poly(siloxane-azometine)s. J Therm Anal Calorim. 2008;92:263-9.

31. Zeldin M, Quian BR, Choi SJ. Mechanism of thermal depolymerization of trimethylsiloxy-terminated polydimethylsiloxane. J Polym Sci. 1983;21:1361-9. 
32. Dvornic PR. Chapter: high temperature stability of polysiloxanes. Gelest Catalog 4000-A: silicon compounds, silanes, and silicones; 2008. p. 441-454.

33. Chou C, Yang MH. Structural effects on the thermal properties of PDPS/PDMS copolymers. J Therm Anal Calorim. 1993;40:657-67.

34. Ramirez C, Abad MJ, Barral L, Cano J, Diez FJ, Lopez J, Montez R, Polo J. Thermal behavior of a polyhedral oligomeric silsesquioxane with epoxy resin cured by diamines. J Therm Anal Calorim. 2003;72:421-9.

35. Peňa-Alonso R, Mariotto G, Gervais C, Babonneau F, Soraru GD. Chem Mat. 2007;19:5694-702.

36. Siqueira RL, Yoshida IVP, Pardini LC, Schiavon MA. Poly(borosiloxanes) as precursors for carbon fiber ceramic matrix composites. Mat Res. 2007;10:147-51.
37. Schiavon MA, Armelin NA, Yoshida VP. Novel poly(borosiloxane) precursors to amorphous $\mathrm{SiBCO}$ ceramics. Mater $\mathrm{Chem}$ Phys. 2008;112:1047-54.

38. Chruściel J, Janowska G, Rybiński P, Ślusarski L. Effect of the top layer modification of polymers on their thermostability and flammability. J Therm Anal Calorim. 2006;84:339-44.

39. Brook MA. Silicon in organic, organometallic and polymer chemistry. New York: Wiley; 2000.

40. Kurian P, Kennedy JP, Kisliuk A, Sokolov A. Poly(pentamethylcyclopentasiloxane). I. Synthesis and characterization. J Polym Sci Part A. 2002;40:1285-92. 